\title{
Metabolism of Reverse Triiodothyronine by Isolated Rat Hepatocytes
}

\author{
Sebo Jan Eelkman Rooda, Marla A. C. van Loon, and Theo J. Visser \\ Department of Internal Medicine III and Clinical Endocrinology, Erasmus University Medical School, Rotterdam, The Netherlands
}

\begin{abstract}
Reverse triiodothyronine $\left(\mathrm{rT}_{3}\right)$ is metabolized predominantly by outer ring deiodination to $3,3^{\prime}$-diiodothyronine $\left(3,3^{\prime}-T_{2}\right)$ in the liver. Metabolism of $\mathbf{r T}_{3}$ and 3,3'- $\mathbf{T}_{2}$ by isolated rat hepatocytes was analyzed by Sephadex LH-20 chromatography, high performance liquid chromatography, and radioimmunoassay, with closely agreeing results. Deiodinase activity was inhibited with propylthiouracil (PTU) and sulfotransferase activity by sulfate depletion or addition of salicylamide or dichloronitrophenol. Normally, little $3,3^{\prime}-T_{2}$ production from $\mathrm{rT}_{3}$ was observed, and ${ }^{125} I^{-}$was the main product of both $3,\left[3^{\prime}-{ }^{125} I\right] T_{2}$ and $\left[3^{\prime}, 5^{\prime}-{ }^{125} I\right] r T_{3}$. PTU inhibited $r \mathbf{T}_{3}$ metabolism but did not affect $3,3^{\prime}-\mathrm{T}_{2}$ clearance as explained by accumulation of $3,3^{\prime}-T_{2}$ sulfate. Inhibition of sulfation did not affect $r T_{3}$ clearance but $3,3^{\prime}-T_{2}$ metabolism was greatly diminished. The decrease in $\mathrm{I}^{-}$formation from $\mathrm{rT}_{3}$ was compensated by an increased recovery of $3,3^{\prime}-T_{2}$ up to $70 \%$ of $\mathbf{r T}_{3}$ metabolized. In conclusion, significant production of $3,3^{\prime}-T_{2}$ from $\mathrm{rT}_{3}$ by rat hepatocytes is only observed if further sulfation is inhibited.
\end{abstract}

\section{Introduction}

In euthyroid subjects the main secretory product of the thyroid is thyroxine $\left(\mathrm{T}_{4}\right){ }^{1}$. Some $3,3^{\prime}, 5$-triiodothyronine $\left(\mathrm{T}_{3}\right)$ is secreted as well, but thyroidal production of $3,3^{\prime}, 5^{\prime}$-triiodothyronine $\left(\mathrm{rT}_{3}\right)$ is negligible. More than $97.5 \%$ of plasma $\mathrm{rT}_{3}$ and $\sim 80 \%$ of plasma $T_{3}$ originate from peripheral deiodination of $T_{4}(1)$. As thyroid hormone bioactivity is exerted largely through $T_{3}$, it is important to understand the regulatory mechanisms of iodothyronine metabolism.

In rats, three types of iodothyronine-deiodinating enzymes have been identified (2). Most likely, the type I deiodinase of liver catalyzes both inner ring deiodination (IRD) and outer ring deiodination (ORD) of iodothyronines (2). A similar enzyme is present in kidney and thyroid (2). Type II deiodinase has been localized in brain, pituitary, brown adipose tissue, and placenta.

This paper was presented in part at the 9th International Thyroid Congress, Sao Paulo, September 1985.

Address correspondence to Dr. Visser, Dept. of Internal Medicine III, Erasmus U. Medical School, P.O. Box 1738, 3000 DR Rotterdam, The Netherlands.

Received for publication 6 November 1986 and in revised form 20 February 1987.

1. Abbreviations used in this paper: DCNP, 2,6-dichloro-4-nitrophenol; $G$, glucuronide; IRD, inner ring deiodination; $O R D$, outer ring deiodination; PTU, propylthiouracil; $\mathrm{rT}_{3}, 3,3^{\prime}, 5^{\prime}$-triiodothyronine; $\mathrm{S}$, sulfate; SAM, salicylamide; $T_{2}$, diiodothyronine, $T_{3}, 3,3^{\prime}, 5$-triiodothyronine; $T_{4}$, thyroxine.

J. Clin. Invest.

(c) The American Society for Clinical Investigation, Inc.

0021-9738/87/06/1740/09 \$1.00

Volume 79, June 1987, 1740-1748
It deiodinates only the outer ring of substrates such as $T_{4}$ and $\mathrm{rT}_{3}(2-4)$. Type III enzyme is found in brain, placenta, and skin, and it is a specific inner ring deiodinase $(2,5)$. Type I deiodinase is inhibited by 6-propylthiouracil (PTU), while types II and III are PTU insensitive (2). Thus, there may be two sources of plasma $\mathrm{rT}_{3}$, namely type I or type III IRD of $\mathrm{T}_{4}$. There are also two pathways of $\mathrm{rT}_{3}$ deiodination, i.e., type I and type II ORD to $3,3^{\prime}$-diiodothyronine $\left(3,3^{\prime}-T_{2}\right)$.

Considering the high rate of $\mathrm{rT}_{3}$ ORD by the type I deiodinase (2), it is likely that little $\mathrm{rT}_{3}$ produced from $\mathrm{T}_{4}$ in the liver is released into the circulation. It would seem, therefore, that most plasma $\mathrm{rT}_{3}$ is derived from type III deiodination of $\mathrm{T}_{4}$, while it is cleared mainly by the liver. This hypothesis is substantiated by measurements of arterio-venous gradients of $\mathrm{rT}_{3}$ across the liver in patients with mild liver failure. ${ }^{2}$

In vivo studies in normal rats have demonstrated that the type I deiodinase is the predominant site for the peripheral production of $T_{3}(6)$. Opposite variation in plasma $T_{3}$ and $\mathrm{rT}_{3}$ concentrations has been observed in a number of clinical situations, in which changes are due to a decrease in both the production of plasma $T_{3}$ and the clearance of plasma $\mathrm{rT}_{3}(7)$. To investigate the potential importance of changes in type I deiodinase activity for the regulation of thyroid hormone metabolism, we initiated studies of the deiodination of $\mathrm{rT}_{3}$ by isolated rat hepatocytes.

Initial results, using outer ring ${ }^{125} \mathrm{I}$-labeled $\mathrm{rT}_{3}$, showed that radioiodide was the main product, but little production of $3,3^{\prime}$ $\mathrm{T}_{2}$ from unlabeled $\mathrm{rT}_{3}$ could be detected by radioimmunoassay (RIA) (8). Further investigations have demonstrated rapid metabolism of added $3,3^{\prime}-\mathrm{T}_{2}$ in rat hepatocytes by sulfation and subsequent ORD of the $3,3^{\prime}-T_{2}$ sulfate $\left(3,3^{\prime}-T_{2} S\right)$ formed (9). $3,3^{\prime}-\mathrm{T}_{2} \mathrm{~S}$ is a far better substrăte for the type I deiodinase than $3,3^{\prime}-T_{2}$ itself (9). This may be the reason for our failure to detect significant production of $3,3^{\prime}-\mathrm{T}_{2}$ from $\mathrm{rT}_{3}$ by liver cells. If so, the yield of $3,3^{\prime}-T_{2}$ produced by this pathway should increase if its further sulfation is inhibited. This hypothesis was tested in the present study using rat hepatocytes with diminished phenol sulfotransferase activity.

\section{Methods}

The materials used are essentially the same as described previously (10). Carrier-free 3,[3'-125 I] $\mathrm{T}_{2}$ and $\left[3^{\prime}, 5^{\prime}-{ }^{125} \mathrm{I}\right] \mathrm{r} \mathrm{T}_{3}$ were prepared in our laboratory by radioiodination of 3-iodothyronine or of $3,3^{\prime}-\mathrm{T}_{2}$ (Henning $\mathrm{GmbH}$, Berlin, Federal Republic of Germany) using the chloramine T method $(11,12)$ and purified by Sephadex LH-20 chromatography. Salicylamide (SAM) and 2,6-dichloro-4-nitrophenol (DCNP) were purchased from Riedel-de Haën AG, Hannover, Federal Republic of Germany. All other chemicals were of the highest quality commercially available.

Hepatocytes. Rat hepatocytes were prepared by collagenase perfusion (10). Monolayers of hepatocytes were obtained by seeding $10^{6}$ cells in 2 $\mathrm{ml}$ culture medium (10) into uncoated $3.5-\mathrm{cm}$ wells of plastic 6-well dishes (Nunc, Roskilde, Denmark). The plates were kept for $4 \mathrm{~h}$ at $37^{\circ} \mathrm{C}$

2. Bauer, A. G. C., J. H. P. Wilson, S. W. J. Lamberts, R. Docter, G. Hennemann, and T. J. Visser, manuscript submitted for publication. 
in a culture stove under atmospheric conditions. Before each experiment, cell viability was tested by trypan blue exclusion and exceeded $85 \%$. Nonviable cells were removed by aspiration of the medium.

General incubation procedures. Incubations were done for $60 \mathrm{~min}$ in $2 \mathrm{ml}$ of Dulbecco's balanced salt solution which contained $1 \mathrm{mM}$ $\mathrm{MgSO}_{4}, 0.1 \%$ bovine serum albumin (BSA), $2 \mathrm{mM}$ glutamine, and 1 $\mathrm{mM}$ vitamin $\mathrm{C}$. Experiments were carried out in triplicate under atmospheric conditions at $37^{\circ} \mathrm{C}$. The dishes were placed on a slightly angled, slowly rotating plate. Substrate levels were $10 \mathrm{nM} \mathrm{rT}_{3}$ or $3,3^{\prime}-\mathrm{T}_{2}$ with or without $0.1 \mu \mathrm{Ci}\left[{ }^{125} \mathrm{I}\right] \mathrm{rT} \mathrm{T}_{3}$ or $\left[{ }^{125} \mathrm{I}\right] 3,3^{\prime}-\mathrm{T}_{2}$, respectively. Sulfation was inhibited with $100 \mu \mathrm{M}$ SAM or $100 \mu \mathrm{M}$ DCNP and deiodination was inhibited with $10 \mu \mathrm{M}$ PTU.

Sulfate depletion. Hepatocytes were preincubated for $30 \mathrm{~min}$ at $37^{\circ} \mathrm{C}$ in Dulbecco's solution which contained $1 \mathrm{mM} \mathrm{MgCl}, 2 \mathrm{mM}$ glutamine, and $1 \mathrm{mM}$ vitamin $C$ with or without $100 \mu \mathrm{M}$ SAM. Incubations were done as described above in medium without $\mathrm{SO}_{4}{ }^{2-}$. Controls were preincubated and incubated in medium containing $\mathrm{MgSO}_{4}$.

Analysis of incubation medium. Incubation media with unlabeled $\mathrm{rT}_{3}$ and 3,3'- $\mathrm{T}_{2}$ were analyzed before and after hydrolysis with specific RIAs $(11,12)$. Hydrolysis of eventual $\mathrm{S}$ conjugates was achieved by addition of $250 \mu \mathrm{l} 1 \mathrm{~N} \mathrm{HCl}$ to $100-\mu \mathrm{l}$ samples and treatment for $1 \mathrm{~h}$ at $80^{\circ} \mathrm{C}(13)$. Thereafter, $300 \mu \mathrm{l} 1 \mathrm{~N} \mathrm{NaOH}$ was added. The nonhydrolyzed samples were treated the same way but without heating. RIA was done in duplicate on $50-\mu 1$ aliquots of the mixtures.

Incubation media with labeled $\mathrm{rT}_{3}$ and $3,3^{\prime}-\mathrm{T}_{2}$ were assayed by column chromatography. An equal volume of $1 \mathrm{~N} \mathrm{HCl}$ was added to $500-\mu \mathrm{l}$ samples and the mixtures were applied to small (bed volume $0.75 \mathrm{ml}$ ) Sephadex LH-20 columns equilibrated in $0.1 \mathrm{~N} \mathrm{HCl}$. Stepwise elution was done by successive application of $2 \times 1 \mathrm{ml} 0.1 \mathrm{~N} \mathrm{HCl}, 6 \times 1 \mathrm{ml}$ $\mathrm{H}_{2} \mathrm{O}, 6 \times 1 \mathrm{ml} 0.1 \mathrm{~N} \mathrm{NaOH}$-ethanol $(9: 1, \mathrm{vol} / \mathrm{vol})$, and $3 \times 1 \mathrm{ml} 0.1 \mathrm{~N}$ $\mathrm{NaOH}$-ethanol (1:1, vol/vol).

High performance liquid chromatography (HPLC). Analysis of $\mathrm{rT}_{3}$ and $3,3^{\prime}-T_{2}$ conjugates and native iodothyronines was accomplished by reverse-phase HPLC. For this we used a $10 \times 0.3-\mathrm{cm}$ CP Spher C18 column (Chrompack, Middelburg, The Netherlands), a model $6000 \mathrm{~A}$ solvent delivery system and a model 440 fixed wavelength detector (Waters Assoc., Millipore Corp., Milford, MA). Flow was $0.6 \mathrm{ml} / \mathrm{min}$ and absorbance was measured at $254 \mathrm{~nm}$. For separation of conjugates a 20:80 vol/vol mixture of acetonitrile and $0.02 \mathrm{M}$ ammonium acetate (pH 4) was used, and for separation of $\mathrm{rT}_{3}$ and 3,3'- $\mathrm{T}_{2}$ a 55:45 vol/vol mixture of methanol and $0.02 \mathrm{M}$ ammonium acetate (pH 4) was employed.

To obtain the conjugates for HPLC analysis, the water fractions of the LH-20 chromatography were pooled, acidified, and rechromatographed. The columns were washed with $2 \mathrm{ml} 0.1 \mathrm{~N} \mathrm{HCl}, 0.5 \mathrm{ml} \mathrm{H}_{2} \mathrm{O}$, and $0.5 \mathrm{ml} 0.1 \mathrm{M}$ ammonia in ethanol. Conjugates were then collected in a subsequent fraction of $1 \mathrm{ml} 0.1 \mathrm{M}$ ammonia in ethanol. The solvent was evaporated at $50^{\circ} \mathrm{C}$ under a stream of $\mathrm{N}_{2}$. To obtain the iodothyronine fraction, medium was processed as above and LH-20 chromatography was modified as follows. After the $\mathrm{H}_{2} \mathrm{O}$ fractions, columns were washed with $0.5 \mathrm{ml} 0.1 \mathrm{M}$ ammonia-ethanol (1:1 vol/vol), and iodothyronines were collected in $1 \mathrm{ml} 0.1 \mathrm{M}$ ammonia in ethanol. The solvent was evaporated as above.

Enzymatic analysis of $r T_{3}$ and 3,3'- $T_{2}$ conjugates. Another method by which the conjugates were identified was by enzymatic hydrolysis with glucuronidase and sulfatase in the presence or absence of saccharic acid lactone (10). Hydrolysis was quantified by LH-20 chromatography and the liberated iodothyronines were identified by HPLC.

Analysis of cell content. Cell-associated radioactivity was extracted after removing the medium by immediate addition of $1 \mathrm{ml} 0.1 \mathrm{~N} \mathrm{NaOH}$. After centrifugation, $0.5 \mathrm{ml}$ of supernatant was chromatographed on LH-20 as described above for medium.

Miscellaneous. The influence of SAM $(10-1000 \mu \mathrm{M})$ and DCNP (1$100 \mu \mathrm{M})$ on the type I deiodinase was tested by measurement of their effects on the release of ${ }^{125} \mathrm{I}^{-}$from $10 \mathrm{nM}\left[{ }^{125} \mathrm{I}\right] \mathrm{rT} \mathrm{T}_{3}$ in incubations with rat liver microsomes (14) in $0.1 \mathrm{M}$ phosphate buffer ( $\mathrm{pH} 7.2$ ), $2 \mathrm{mM}$ EDTA, and $5 \mathrm{mM}$ dithiothreitol (DTT). The free fractions of $\mathrm{rT}_{3}$ and $3,3^{\prime}-T_{2}$ in incubation medium were determined by equilibrium dialysis.
Cellular ATP content was measured according to the method described by Jaworek et al. (15).

Data analysis. In each experiment, $\mathrm{I}^{-}$production was corrected for the amount of $\mathrm{I}^{-}$recovered from control incubations, while the $3,3^{\prime}-\mathrm{T}_{2}$ production from $\mathrm{rT}_{3}$ was corrected for the slight contamination of the $3,3^{\prime}-T_{2}$ fraction with $r T_{3}$. Production of unlabeled 3,3'- $T_{2}$ was corrected for $\mathrm{rT}_{3}$ crossreactivity $(0.03 \%)$ in the $3,3^{\prime}-\mathrm{T}_{2}$ RIA. Statistical analysis was done by Student's $t$ test for unpaired data.

\section{Results}

Sephadex LH-20 chromatography. The Sephadex LH-20 chromatographic pattern of $\mathrm{I}^{-}, 3,3^{\prime}-\mathrm{T}_{2} \mathrm{~S}, 3,3^{\prime}-\mathrm{T}_{2}$, and $\mathrm{rT}_{3}$ is depicted in Fig. 1. More than $97 \%$ of ${ }^{125} \mathrm{I}^{-}$activity was found in fractions 1-4. Recovery of $3,3^{\prime}-\mathrm{T}_{2} \mathrm{~S}$, eluting in the $\mathrm{H}_{2} \mathrm{O}$ fractions, was $>97.5 \%$. All other $3,3^{\prime}-\mathrm{T}_{2}$ and $\mathrm{rT}_{3}$ conjugates eluted also in fractions 5-9. Approximately $97 \%$ of $3,3^{\prime}-\mathrm{T}_{2}$ was found in fractions $10-15$, while fractions $16-18$ contained at least $95 \%$ of $\mathrm{rT}_{3}$. Thus, there was little overlap of fractions containing the different metabolites, although some $4 \%$ of $\mathrm{rT}_{3}$ eluted in the $3,3^{\prime}-\mathrm{T}_{2}$ fractions. This was not due to contamination of $\mathrm{rT}_{3}$ tracer with $3,3^{\prime}-\mathrm{T}_{2}$ as checked by HPLC.

Time dependence of $3,3^{\prime}-T_{2}$ and $r T_{3}$ metabolism. Fig. 2 shows the LH-20 analysis of the main products in the medium generated from 3, $3^{\prime}-\mathrm{T}_{2}$ and $r \mathrm{~T}_{3}$ as a function of time of incubation in the absence or presence of SAM. In $3,3^{\prime}-T_{2}$ incubations $I^{-}$

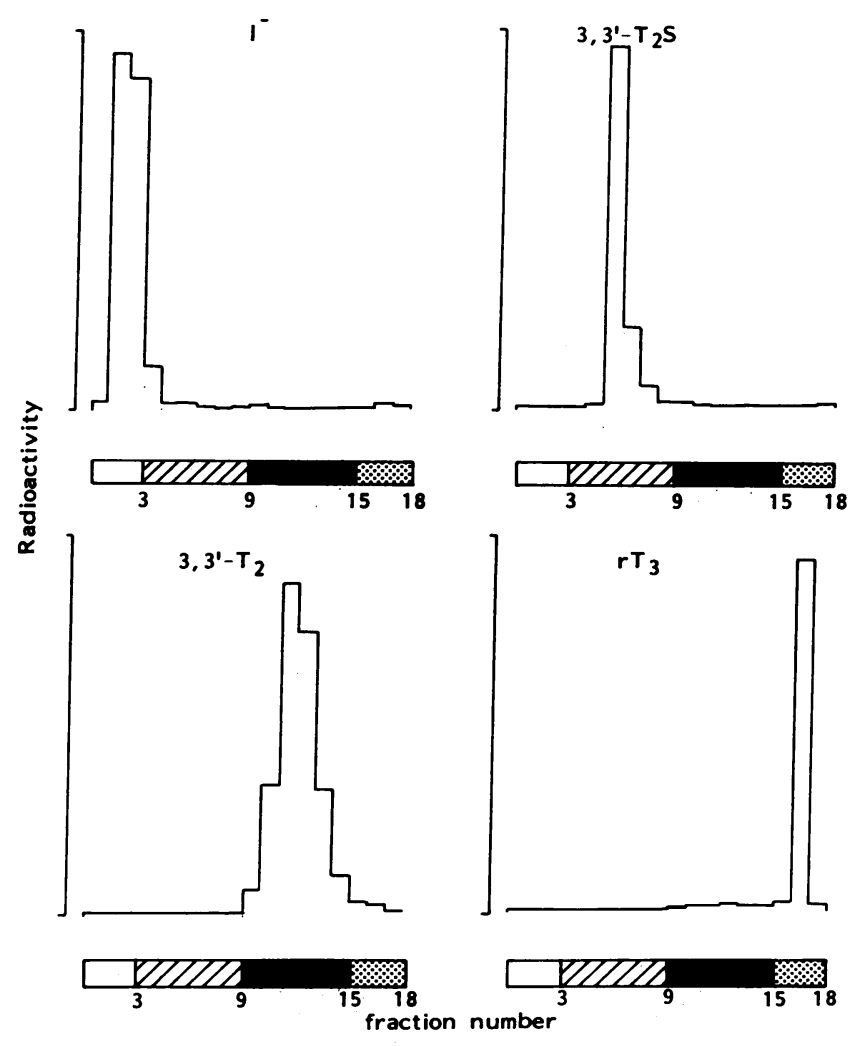

Figure 1. Sephadex LH-20 chromatography of iodide, 3,3'- ${ }_{2} \mathrm{~S}, 3,3^{\prime}-$ $T_{2}$, and $\mathrm{rT}_{3}$. Each ${ }^{125} \mathrm{I}$-labeled compound was applied separately in 1 $\mathrm{ml} 0.5 \mathrm{~N} \mathrm{HCl}$ to a small Sephadex LH-20 column with a bed volume of $0.75 \mathrm{ml}$ which was equilibrated in $0.1 \mathrm{~N} \mathrm{HCl}$. Subsequently, columns were eluted using $2 \mathrm{ml} 0.1 \mathrm{~N} \mathrm{HCl}(\square), 6 \mathrm{ml} \mathrm{H}_{2} \mathrm{O}(0), 6 \mathrm{ml}$ ethanol- $0.1 \mathrm{~N} \mathrm{NaOH}(1: 9 \mathrm{vol} / \mathrm{vol})(\square)$, and finally $3 \mathrm{ml}$ ethanol- $0.1 \mathrm{~N}$ $\mathrm{NaOH}(1: 1 \mathrm{vol} / \mathrm{vol})(\mathrm{\Xi})$. Each 1-ml fraction was counted for radioactivity. 

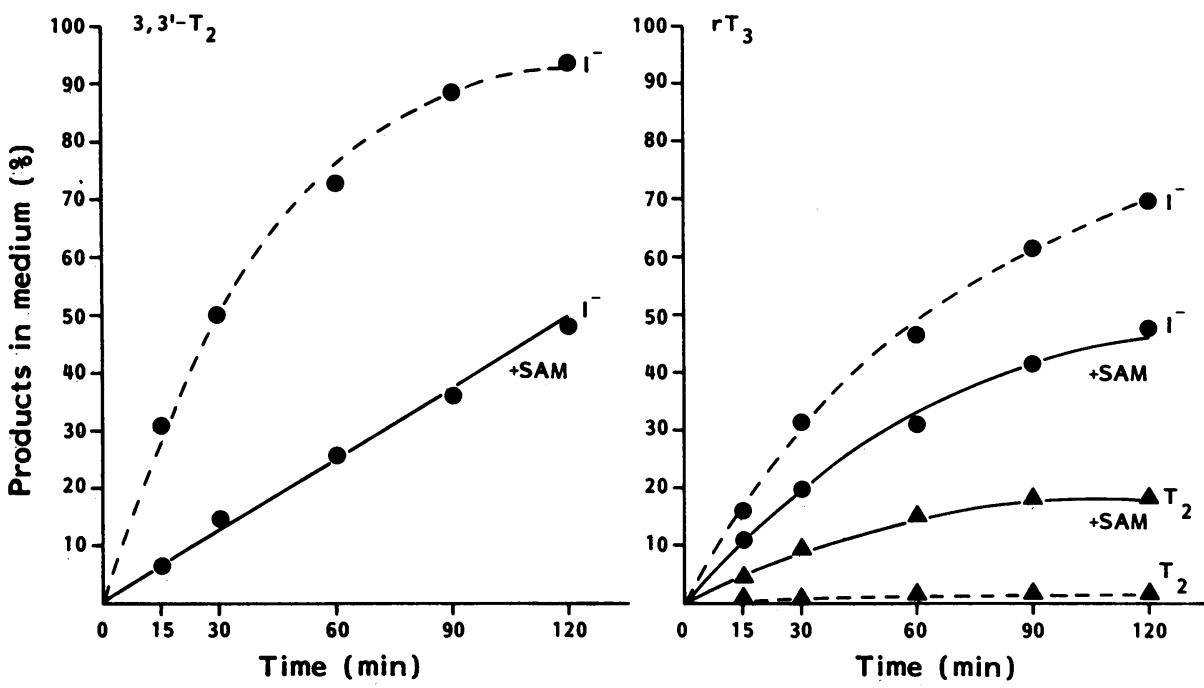

Figure 2. Time dependence of 3,3'- $\mathrm{T}_{2}$ and $\mathrm{rT}_{3}$ metabolism. $10 \mathrm{nM} 3,3^{\prime}-\mathrm{T}_{2}$ or $\mathrm{rT}_{3}$ with $0.1 \mu \mathrm{Ci}\left[{ }^{125} \mathrm{I}\right] 3,3^{\prime}-\mathrm{T}_{2}$ or $\left[{ }^{125} \mathrm{I}\right] \mathrm{r} \mathrm{T}_{3}$ were incubated with $10^{6}$ hepatocytes in $2 \mathrm{ml}$ S-supplemented Dulbecco's medium without (dashed line) or with (solid line) $100 \mu \mathrm{M}$ SAM. After 15, 30, 60,90 , and $120 \mathrm{~min}$ incubation was stopped by removing the medium that was analyzed by Sephadex LH-20 chromatography. Production of $\mathrm{I}^{-}$from 3,3'$\mathrm{T}_{2}$ (left) and of $\mathrm{I}^{-}$and 3,3'- $\mathrm{T}_{2}$ from $\mathrm{rT}_{3}$ (right) are expressed as percentage of total radioactivity in medium. Note that no correction was made for the fact that the specific radioactivity of the $\mathrm{I}^{-}$and $3,3^{\prime}-T_{2}$ produced is only half of that of added $\mathrm{rT}_{3}$. Data are taken from a representative experiment with results that were reproduced on at least two other occasions. was the main metabolite, the amount of which was inversely correlated with that of remaining $3,3^{\prime}-\mathrm{T}_{2}$. The semi-logarithmic plot of the latter against time demonstrated that the disappearance of 3,3'- $T_{2}$ followed first order kinetics with a rate constant of $0.031 \mathrm{~min}^{-1}$. Addition of SAM strongly inhibited $\mathrm{I}^{-}$formation. In the presence of this inhibitor $3,3^{\prime}-\mathrm{T}_{2}$ clearance remained a first order process with a rate constant of $0.007 \mathrm{~min}^{-1}$.

In $\mathrm{rT}_{3}$ incubations $\mathrm{I}^{-}$was also the main metabolite found, while 3,3'- $T_{2}$ formation was undetectable under control conditions. Addition of SAM resulted in the inhibition of $\mathrm{I}^{-}$release

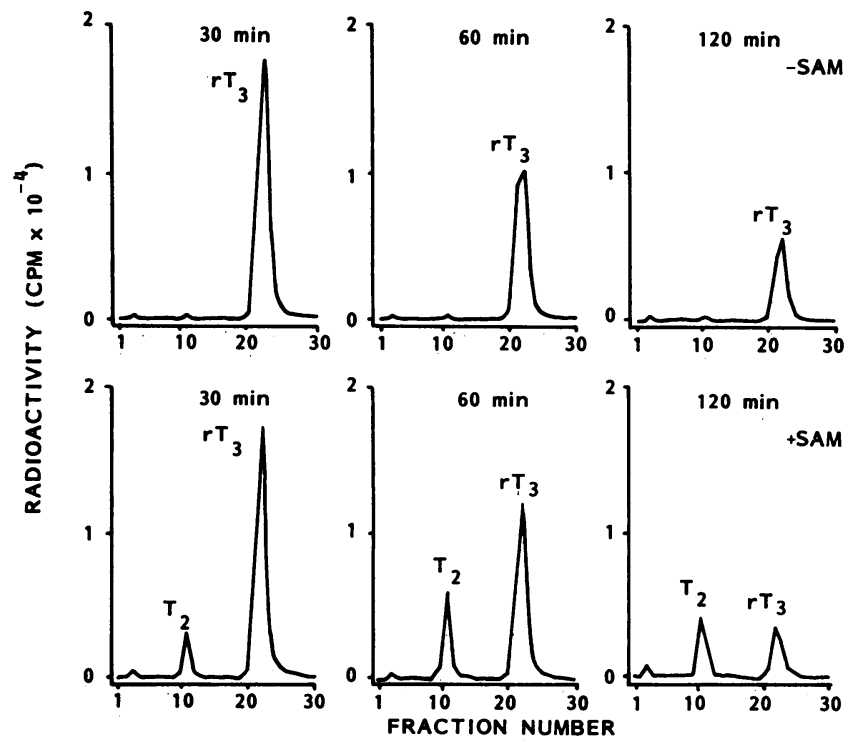

Figure 3. HPLC analysis of iodothyronines recovered from incubations of $\mathrm{rT}_{3}$ with hepatocytes. Parallel samples of the same incubations described in Fig. 2 were chromatographed on Sephadex LH-20 modified such that $3,3^{\prime}-\mathrm{T}_{2}$ and $\mathrm{rT}_{3}$ were eluted collectively with $0.1 \mathrm{M}$ ammonia in ethanol (see Methods). Solvent was evaporated, the residue taken up in a 55:45 vol/vol mixture of methanol and $0.02 \mathrm{M}$ ammonium acetate (pH 4) and subjected to HPLC using the same solvent at a flow of $0.6 \mathrm{ml} / \mathrm{min}$. Fractions of $0.3 \mathrm{ml}$ were collected and counted for radioactivity. The elution position of $3,3^{\prime}-\mathrm{T}_{2}$ and $r \mathrm{~T}_{3}$ was determined by monitoring absorbance at $254 \mathrm{~nm}$ after application of pure synthetic substances. with a reciprocal accumulation of $3,3^{\prime}-\mathrm{T}_{2}$. Clearance of $r \mathrm{~T}_{3}$ was also a first order process, characterized by a rate constant of $0.014 \mathrm{~min}^{-1}$, which was not influenced by SAM. The identity of the $3,3^{\prime}-T_{2}$ produced was further tested by HPLC analysis (Fig. 3). Little or no 3,3'- $\mathrm{T}_{2}$ formation could be detected in control incubations by HPLC, while in the presence of SAM 3,3'- $T_{2}$ accumulation was substantial. Relative to the quantity of $\mathrm{rT}_{3}$ remaining after 30,60 , and $120 \mathrm{~min}, 3,3^{\prime}-\mathrm{T}_{2}$ accumulation amounted to 11,33 , and $80 \%$, respectively.

Dose-dependent effects of SAM (Fig. 4). As previously shown (10), addition of $10 \mu \mathrm{M}$ PTU greatly inhibited ${ }^{125} \mathrm{I}^{-}$production in incubations with $3,3^{\prime}-T_{2}$, but did not affect the clearance of this compound. Most radioactivity recovered from the medium now eluted in the water fractions of the LH-20 chromatography, which was shown to consist mainly of $3,3^{\prime}-\mathrm{T}_{2} \mathrm{~S}$ (see below). Addition of PTU also led to an increase in cell-associated radioactivity, from $<5 \%$ in the absence to $22 \%$ in the presence of the inhibitor. This radioactivity was predominantly in the form of conjugates and presumably represented the accumulation of $3,3^{\prime}-\mathrm{T}_{2} \mathrm{~S}$ within the cells. Addition of $10-1,000 \mu \mathrm{M}$ SAM resulted in a progressive decrease in the clearance of $3,3^{\prime}-T_{2}$ independent of PTU. This was indicated by the parallel decrease of $\mathrm{I}^{-}$formation without PTU and of 3,3'- $\mathrm{T}_{2} \mathrm{~S}$ accumulation with PTU. With the SAM-induced inhibition of $3,3^{\prime}-\mathrm{T}_{2}$ clearance there was an increase in cell-associated $3,3^{\prime}-\mathrm{T}_{2}$, irrespective of PTU.

In contrast to $3,3^{\prime}-\mathrm{T}_{2}, \mathrm{rT}_{3}$ metabolism was almost completely blocked by PTU but was not affected by even 1,000 $\mu \mathrm{M}$ SAM. In the absence of SAM, little 3,3'- $T_{2}$ production was observed in the medium once again, and no $3,3^{\prime}-T_{2}$ was detectable in the cells. With increasing SAM concentrations, $3,3^{\prime}-\mathrm{T}_{2}$ accumulation in the medium was accompanied by a rise in cellular radioactivity from 5 to $12 \%$, part of which was in the form of $3,3^{\prime}-T_{2}$. Based on the dose-effect relationship for SAM on the metabolism of both $3,3^{\prime}-\mathrm{T}_{2}$ and $\mathrm{rT}_{3}, 100 \mu \mathrm{M}$ was chosen as the near-maximal sulfotransferase inhibitory concentration.

3, $3^{\prime}-T_{2}$ and $r T_{3}$ metabolism; correlation between $\mathrm{LH}-20$ and $R I A$. Table I shows the effects of $100 \mu \mathrm{M}$ SAM or DCNP or 10 $\mu \mathrm{M}$ PTU on $3,3^{\prime}-\mathrm{T}_{2}$ and $\mathrm{rT}_{3}$ metabolism as measured by LH20 chromatography or by RIA. To compare the results obtained by these two methods it has to be taken into account that (a) LH-20 data are not corrected for cell-associated radioactivity 



Figure 4. Dose-effect relationship of SAM on the metabolism of $3,3^{\prime}-\mathrm{T}_{2}$ and $\mathrm{rT}_{3}$. Hepatocytes were incubated with $10 \mathrm{nM}\left[{ }^{125} \mathrm{I}\right] 3,3^{\prime}-\mathrm{T}_{2}$ or $\left[{ }^{125} \mathrm{I}\right] \mathrm{rT}_{3}$ in S-supplemented Dulbecco's medium. SAM was added at concentrations of 10,100 , and $1,000 \mu \mathrm{M}$, and PTU at 10 $\mu \mathrm{M}$. After 60 min medium was removed and cells were extracted immediately by adding $1 \mathrm{ml} 0.1 \mathrm{~N}$ $\mathrm{NaOH}$. Medium samples of $0.5 \mathrm{ml}$ or supernatant obtained after centrifugation of the cellular extracts were acidified with $0.5 \mathrm{ml} 1 \mathrm{~N} \mathrm{HCl}$ and chromatographed on LH-20. Products in medium are given as percentage of radioactivity in medium, while products in cells are expressed as percentage of total radioactivity added. Completion of medium radioactivity to $100 \%$ represents the proportion of unaltered substrate. No correction is made for difference in specific radioactivity between substrate and products in $\mathrm{rT}_{3}$ incubations. Typical results are shown from one out of three closely agreeing experiments. ( $\square$ ) $\mathrm{I}^{-} ;(\mathbb{a})$ conjugates; ( $(\mathbf{)}$ $3,3^{\prime}-\mathrm{T}_{2}$; and $(\mathbb{\otimes}) \mathrm{rT}_{3}$.

(Fig. 4), and (b) the specific radioactivity of the $3,3^{\prime}-\mathrm{T}_{2}$ produced is half that of added $\mathrm{rT}_{3}$. With this in mind there exists a good correlation between the two methods.

After incubation for $60 \mathrm{~min}$ with $\left[{ }^{125} \mathrm{I}\right] 3,3^{\prime}-\mathrm{T}_{2}, 80 \%$ of radioactivity in the medium was recovered as ${ }^{125} \mathrm{I}^{-}$. SAM, DCNP, and PTU reduced $\mathrm{I}^{-}$formation by 64,57 , and $95 \%$, and $3,3^{\prime}-\mathrm{T}_{2}$ clearance by 59,54 , and $10 \%$, respectively. If remaining $3,3^{\prime}-\mathrm{T}_{2}$ in medium was measured by RIA, inhibition of the clearance of $3,3^{\prime}-\mathrm{T}_{2}$ by these treatments was 52,62 , and $1 \%$, respectively. The 3, $3^{\prime}-\mathrm{T}_{2} \mathrm{~S}$ accumulating in the presence of PTU as observed in the incubations with [ $\left.{ }^{125} \mathrm{I}\right] 3,3^{\prime}-\mathrm{T}_{2}$ was largely recovered as immunoreactive $3,3^{\prime}-T_{2}$ after hydrolysis of medium from parallel incubations with unlabeled $3,3^{\prime}-T_{2}$. No $3,3^{\prime}-T_{2}$ was liberated by hydrolysis in all other experimental conditions.

Table I. Comparison of RIA and Sephadex LH-20 Analyses of the Effects of SAM, $D C N P$, and PTU on the Metabolism of 3,3'- $T_{2}$ and $r T_{3}$ by Rat Hepatocytes

\begin{tabular}{|c|c|c|c|c|c|c|c|c|c|}
\hline \multirow[b]{3}{*}{ Condition } & \multicolumn{9}{|c|}{ Products in medium } \\
\hline & \multicolumn{5}{|c|}{ LH-20 } & \multicolumn{4}{|c|}{ RIA } \\
\hline & $n$ & $\mathrm{I}^{-}$ & Conjugates & $3,3^{\prime}-\mathrm{T}_{2}$ & $\mathrm{rT}_{3}$ & $n$ & $3,3^{\prime}-\mathrm{T}_{2}(-)$ & $3,3^{\prime}-T_{2}(+)$ & $\mathrm{rT}_{3}$ \\
\hline \multicolumn{10}{|c|}{$3,3^{\prime}-\mathrm{T}_{2} 30 \mathrm{~min}$} \\
\hline Control & 9 & $48.2 \pm 4.0$ & $3.9 \pm 0.6$ & $44.5 \pm 4.4$ & & 6 & $44.9 \pm 2.9$ & $48.8 \pm 2.5$ & \\
\hline SAM & 8 & $11.5 \pm 1.9^{*}$ & $2.3 \pm 0.2^{r}$ & $83.5 \pm 1.9^{*}$ & & 4 & $67.7 \pm 2.2^{*}$ & $68.8 \pm 2.2^{*}$ & \\
\hline DCNP & 6 & $17.4 \pm 2.1^{*}$ & $2.2 \pm 0.3^{\prime}$ & $77.5 \pm 2.3^{*}$ & & 3 & $63.8 \pm 0.9^{\ddagger}$ & $64.6 \pm 3.3^{\S}$ & \\
\hline PTU & 4 & $4.7 \pm 1.3^{*}$ & $26.3 \pm 5.3^{*}$ & $65.6 \pm 6.5^{\prime \prime}$ & & 3 & $45.8 \pm 2.4$ & $63.4 \pm 1.3^{8}$ & \\
\hline \multicolumn{10}{|c|}{$3,3^{\prime}-\mathrm{T}_{2} 60 \mathrm{~min}$} \\
\hline Control & 10 & $79.0 \pm 2.4$ & $5.7 \pm 1.2$ & $12.9 \pm 1.6$ & & 6 & $12.7 \pm 1.0$ & $16.1 \pm 1.3$ & \\
\hline SAM & 9 & $28.3 \pm 3.3^{*}$ & $4.6 \pm 0.8$ & $63.4 \pm 3.5^{*}$ & & 5 & $54.9 \pm 3.3^{*}$ & $55.9 \pm 4.2^{*}$ & \\
\hline DCNP & 6 & $33.7 \pm 4.9^{*}$ & $5.6 \pm 0.9$ & $58.5 \pm 5.8^{*}$ & & 3 & $45.9 \pm 8.5^{*}$ & $48.5 \pm 5.8^{*}$ & \\
\hline PTU & 5 & $4.4 \pm 1.3^{*}$ & $68.9 \pm 2.4^{*}$ & $21.8 \pm 3.2^{11}$ & & 3 & $13.7 \pm 2.6$ & $52.8 \pm 3.8^{*}$ & \\
\hline \multicolumn{10}{|l|}{$\mathrm{rT}_{3} 60 \mathrm{~min}$} \\
\hline Control & 11 & $47.7 \pm 3.9$ & $1.4 \pm 0.2$ & $0.6 \pm 0.1$ & $43.9 \pm 3.3$ & 6 & $1.8 \pm 0.4$ & $1.9 \pm 0.6$ & $53.8 \pm 3.9$ \\
\hline SAM & 10 & $34.5 \pm 3.2^{\prime \prime}$ & $1.8 \pm 0.3$ & $14.5 \pm 0.5^{*}$ & $42.7 \pm 2.9$ & 5 & $24.7 \pm 2.5^{*}$ & $24.9 \pm 2.3^{*}$ & $53.9 \pm 4.6$ \\
\hline DCNP & 6 & $44.5 \pm 4.3$ & $2.2 \pm 0.4$ & $16.9 \pm 1.9^{*}$ & $33.1 \pm 6.0$ & 3 & $24.6 \pm 3.1^{*}$ & $25.9 \pm 1.9^{*}$ & $30.9 \pm 6.7^{\prime \prime}$ \\
\hline PTU & 5 & $1.8 \pm 0.6^{*}$ & $5.3 \pm 0.7^{*}$ & $-0.4 \pm 0.3^{\ddagger}$ & $87.0 \pm 2.0^{*}$ & 3 & $2.1 \pm 0.8$ & $1.7 \pm 0.9$ & $84.8 \pm 3.0^{\ddagger}$ \\
\hline
\end{tabular}

$10 \mathrm{nM}$ labeled or unlabeled $3,3^{\prime}-\mathrm{T}_{2}$ or $\mathrm{rT}_{3}$ were incubated for 30 or $60 \mathrm{~min}$ at $37^{\circ} \mathrm{C}$ with $10^{6}$ rat hepatocytes in 2 ml S-supplemented Dulbecco's medium with or without $100 \mu \mathrm{M}$ SAM or DCNP or $10 \mu \mathrm{M}$ PTU. Radioactive products were separated on Sephadex LH-20 and unlabeled 3,3'- ${ }_{2}$, and $\mathrm{rT}_{3}$ were measured by RIA before $(-)$ and after $(+)$ hydrolysis as described in Methods. Since acid treatment did not change $\mathrm{rT}_{3}$ levels, mean values of these two measurements are given. RIA values are expressed as percentage of iodothyronines measured after incubations without cells. The results are given as the mean $\pm \mathrm{SE}$ of the number of observations indicated. Statistical analysis of differences between experimental and control conditions was done by Student's unpaired $t$ test: ${ }^{*} P<0.001$. ${ }^{\ddagger} P<0.005$. ${ }^{\S} P<0.01$. $\quad$ " $P<0.025$. ' $P<0.05$. 
After incubation for $60 \mathrm{~min}$ with $\left[{ }^{125} \mathrm{I}\right] \mathrm{rT}_{3}, 48 \%$ of radioactivity in the medium was accounted for by ${ }^{125} \mathrm{I}^{-}$, while the sum of the conjugate and $3,3^{\prime}-T_{2}$ fractions was only $2 \%$. Again, $\mathrm{rT}_{3}$ disappearance was not changed by $\mathrm{SAM}$, but $\mathrm{I}^{-}$formation was decreased by $13.2 \%\left(\sim 2.6 \mathrm{nM} \mathrm{I}^{-}\right)$while $3,3^{\prime}-\mathrm{T}_{2}$ accumulation was increased by $13.9 \%\left(\sim 2.8 \mathrm{nM} \mathrm{3,3}-\mathrm{T}_{2}\right)$. These results correspond with an increase of immunoassayable $3,3^{\prime}-\mathrm{T}_{2}$ by


by LH-20 chromatography and by RIA, it was calculated that with SAM 51 and 54\%, respectively, of the amount of $\mathrm{rT}_{3}$ cleared was recovered as medium $3,3^{\prime}-T_{2}$. Similar results were obtained with DCNP, except that the acceleration of $\mathrm{rT}_{3}$ metabolism seen with this inhibitor was different. PTU inhibited $\mathrm{rT}_{3}$ disappearance from the medium by 77 and $67 \%$ as estimated by LH-20 and RIA, respectively.

$S$ dependence of 3,3'- $T_{2}$ and $r T_{3}$ metabolism. As discussed above, $3,3^{\prime}-T_{2}$ was metabolized predominantly by successive sulfation and ORD. The small amount of conjugates found after incubation of 3,3'- $\mathrm{T}_{2}$ in S-containing medium (Fig. 5) was shown by HPLC to consist of similar proportions of $3,3^{\prime}-T_{2}$ glucuronide $\left(3,3^{\prime}-\mathrm{T}_{2} \mathrm{G}\right)$ and $3,3^{\prime}-\mathrm{T}_{2} \mathrm{~S}$ (Fig. 6). In the presence of PTU, $\mathrm{I}^{-}$formation was again strongly suppressed (Fig. 5), while radioactivity in the conjugate fraction almost entirely eluted in the position of $3,3^{\prime}-T_{2} S$ with no change in the absolute amount of $3,3^{\prime}-T_{2} G$ recovered (Fig. 6). If cells were preincubated with $\mathrm{S}$-free medium and incubated with $3,3^{\prime}-T_{2}$ in this medium plus PTU, conjugation and clearance were diminished by $55 \%$. A further reduction in $3,3^{\prime}-T_{2}$ conjugation to $30 \%$ was observed if SAM was added to the preincubation, while the experiment was otherwise conducted under the same S-free conditions (Fig. 5). HPLC analysis of the conjugate fraction demonstrated that $3,3^{\prime}-\mathrm{T}_{2} \mathrm{~S}$ formation was virtually blocked, and that now most radioactivity eluted in the position of $3,3^{\prime}-\mathrm{T}_{2} \mathrm{G}$ (Fig. 6). In the absence of PTU, $\mathrm{I}^{-}$release was decreased from 74 to $38 \%$ by omission of $S$ from the medium, and further to $17 \%$ after addition of SAM to the preincubation. However, conjugates represented an increasing proportion of the radioactivity in the medium, i.e., 7, 10 , and $15 \%$, respectively (Fig. 5). HPLC revealed that this increase was totally accounted for by a rise in $3,3^{\prime}-T_{2} G$ (Fig. 6).

Clearance of $\mathrm{rT}_{3}$ was not $\mathrm{S}$ dependent. Iodide production, however, decreased from $48 \%$ in the presence of $\mathrm{S}$ to $38 \%$ in the absence of S, and further to $33 \%$ after preincubation with SAM. The loss of $\mathrm{I}^{-}$was completely compensated for by the accumulation of $3,3^{\prime}-\mathrm{T}_{2}$, which amounted to 1,9 , and $14 \%$ under these conditions, respectively (Fig. 5). In S-supplemented incubations the conjugate fraction contained small amounts of $\mathrm{rT}_{3} \mathrm{G}, 3,3^{\prime}-\mathrm{T}_{2} \mathrm{G}$, and $3,3^{\prime}-\mathrm{T}_{2} \mathrm{~S}$. S depletion induced an increase in conjugates mostly in the form of $3,3^{\prime}-T_{2} G$, although even after preincubation with SAM the conjugate fraction comprised only $5 \%$ of medium radioactivity. Inhibition of deiodination by PTU augmented the appearance of conjugates in S-replete incubations (Table I, Fig. 6). In S-deplete cultures, addition of PTU led to a decrease in $T_{2} G$ and an increase in $\mathrm{rT}_{3} \mathrm{G}$ without a change in the total amount of conjugate formed (Fig. 6).

Effect of substrate concentration on $\mathrm{rT}_{3}$ metabolism (Fig. 7). In S-replete incubations, progressive increases in unlabeled $\mathrm{rT}_{3}$ concentration from 1 to $1,000 \mathrm{nM}$ led to minimal increments in the recovery of immunoassayable $3,3^{\prime}-T_{2}$ from the medium. Medium 3,3'- $\mathrm{T}_{2}$ ranged from undetectable after incubation with $1 \mathrm{nM} \mathrm{rT}_{3}$ until maximally 1.9 pmol per dish $(0.1 \%)$ at 1,000 $\mathrm{nM} \mathrm{rT} \mathrm{r}_{3}$. After addition of SAM, accumulation of $3,3^{\prime}-\mathrm{T}_{2}$ rose from $0.8 \mathrm{pmol} / \mathrm{dish}(38 \%)$ at $1 \mathrm{nM} \mathrm{rT}_{3}$ to $29.7 \mathrm{pmol} / \mathrm{dish}(1.5 \%)$ at $1,000 \mathrm{nM} \mathrm{rT}_{3}$. The results indicated that $3,3^{\prime}-\mathrm{T}_{2}$ accumulation under these conditions was a saturable process; it was half-maximal between 10 and $100 \mathrm{nM}$ rT $_{3}$. Cell-associated 3,3'- $T_{2}$ was similarly dependent on substrate concentration.

Effects of SAM and DCNP on free substrate levels, cellular integrity, and deiodinase activity (Table II). In the absence of inhibitors, the free fraction of 3,3'- $\mathrm{T}_{2}$ and $\mathrm{rT}_{3}$ in Dulbecco's medium containing $0.1 \%$ BSA was 8.5 and $4.9 \%$, respectively. Up to $1,000 \mu \mathrm{M}$, SAM did not influence the free $3,3^{\prime}-\mathrm{T}_{2}$ and $\mathrm{rT}_{3}$ fractions. DCNP had no effect on free $3,3^{\prime}-\mathrm{T}_{2}$, while there was a dose-dependent increase in free $\mathrm{rT}_{3}$ up to $7.8 \%$ at $100 \mu \mathrm{M}$ DCNP.

Up to $100 \mu \mathrm{M}, \mathrm{SAM}$ did not inhibit $\mathrm{rT}_{3}$ deiodination by rat liver microsomes, but a $25 \%$ reduction of $\mathrm{I}^{-}$release was observed at $1,000 \mu \mathrm{M}$ SAM. In contrast, $100 \mu \mathrm{M}$ DCNP resulted in a $65 \%$ lowering of deiodinase activity, while only slight inhibition was noted at $10 \mu \mathrm{M}$.

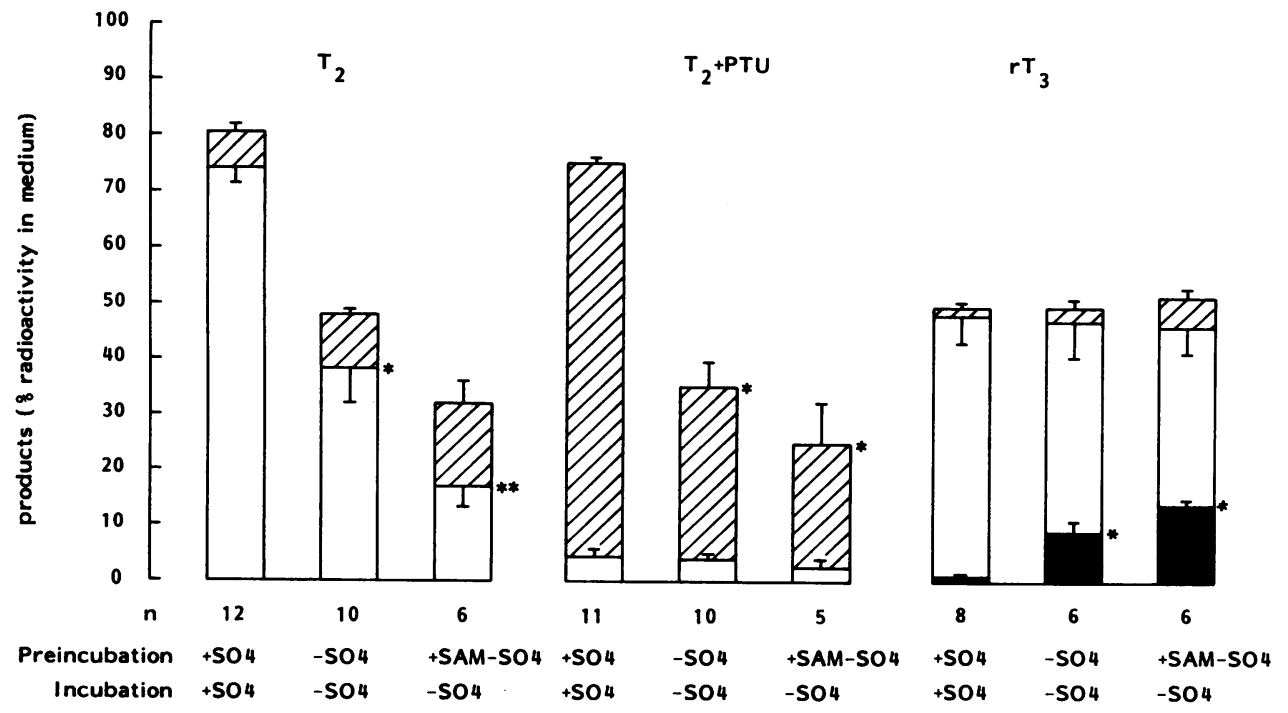

Figure 5. S dependence of 3,3'- $\mathrm{T}_{2}$ and $\mathrm{rT}_{3}$ metabolism. Monolayers of $10^{6}$ hepatocytes were preincubated for $30 \mathrm{~min}$ in S-supplemented medium or in S-free medium plus or minus $100 \mu \mathrm{M}$ SAM. Subsequently, incubations were performed for 60 min with $10 \mathrm{nM}\left[{ }^{125} \mathrm{I}\right] 3,3^{\prime}-\mathrm{T}_{2}$ or $\left[{ }^{125} \mathrm{I}\right] \mathrm{r} \mathrm{T}_{3}$ in S-replete or -deplete medium. PTU was added at $10 \mu \mathrm{M}$. Medium was analyzed by Sephadex LH-20 chromatography and data are expressed as mean $\pm S E$ of the number of observations indicated. Completion of medium radioactivity to $100 \%$ represents the proportion of unaltered substrate. No correction is made for difference in specific radioactivity between substrate and products in $\mathrm{rT}_{3}$ incubations. (ㅁ) $\mathrm{I}^{-}$; (田) conjugates; and ( $(\square) 3,3^{\prime}-\mathrm{T}_{2}$. ${ }^{*}$ Significant difference with preincubation $+\mathrm{SO}_{4}{ }^{2-}, P<0.001$. ${ }^{* *}$ Significant difference with preincubation $-\mathrm{SO}_{4}{ }^{2-}, P$ $<0.05$. 


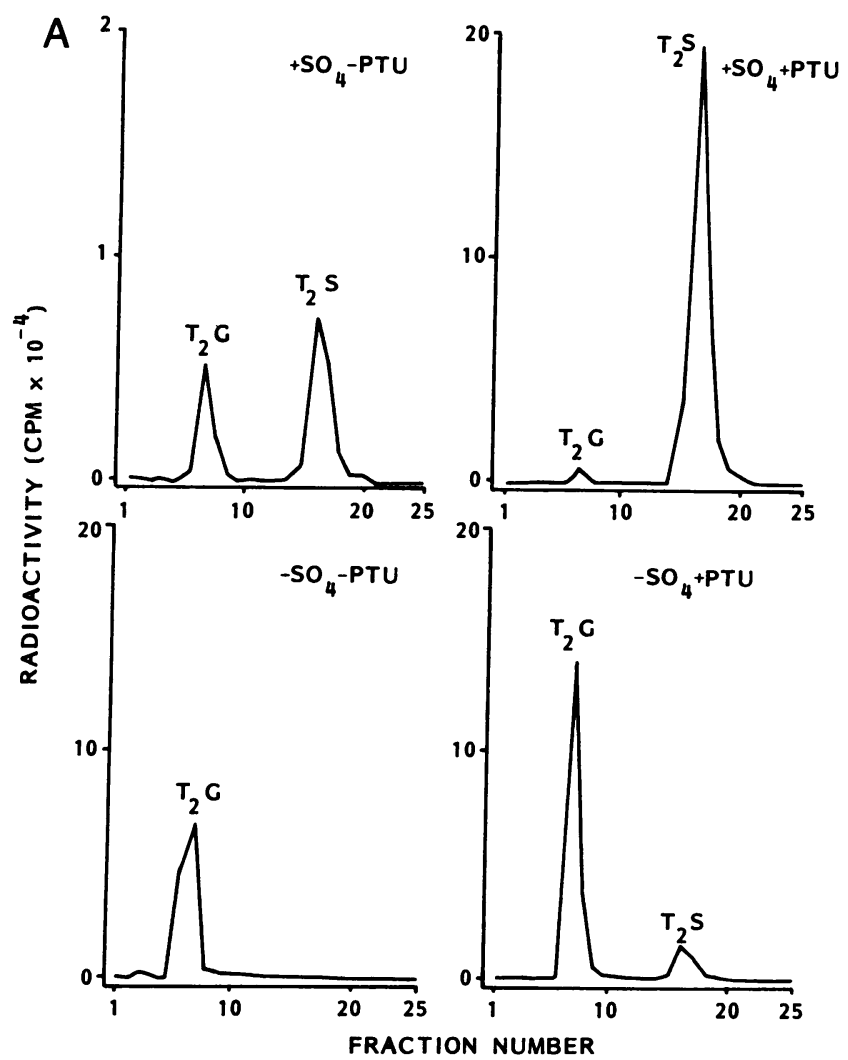

Figure 6. HPLC analysis of conjugates generated in incubations of $(A)$ $3,3^{\prime}-\mathrm{T}_{2}$ and $(B) \mathrm{rT}_{3}$ with hepatocytes. Incubations were done with $\mathrm{S}-$ replete or -deplete cells after preincubation in medium with $S$ or in medium without $S$ plus $100 \mu \mathrm{M}$ SAM as described in the legend to Fig. 5. Conjugates were isolated on Sephadex LH-20, concentrated on a second LH-20 column, and collected in ammonia-ethanol as described in Methods. After evaporation, the residue was analyzed by HPLC using a 20:80 vol/vol mixture of acetonitrile and $0.02 \mathrm{M} \mathrm{am}$ -

Cell viability as assessed by ATP measurements was not affected by SAM. However, a 35\% reduction of cellular ATP was found after incubation with $100 \mu \mathrm{M}$ DCNP.

\section{Discussion}

The occurrence of $\mathrm{rT}_{3}$ and $3,3^{\prime}-\mathrm{T}_{2}$ in rat thyroid as well as in rat plasma has already been reported by Roche et al. in 1955 (16-

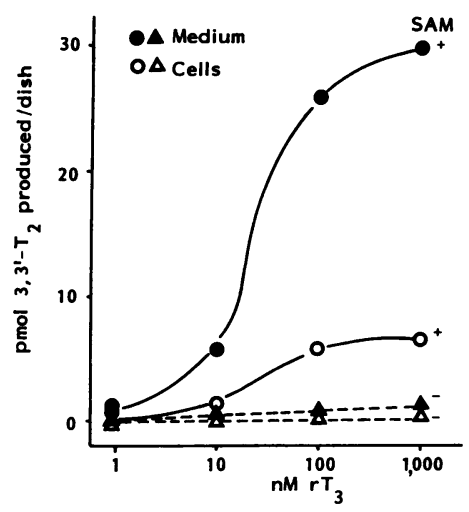

Figure 7. Conversion of $\mathrm{rT}_{3}$ to $3,3^{\prime}-T_{2}$ by rat hepatocytes as a function of substrate concentration. Monolayers of $10^{6}$ hepatocytes were incubated for $60 \mathrm{~min}$ with 1 $1,000 \mathrm{nM}$ unlabeled $\mathrm{rT}_{3}$ in Dulbecco's medium containing $S$ with or without $100 \mu$ M SAM. 3,3'- $T_{2}$ content was measured by RIA in duplicate in $50-\mu \mathrm{l}$ aliquots of medium or $0.1 \mathrm{~N}$ $\mathrm{NaOH}$ extracts of cells. Data are taken from a representative experiment repeated on three different occasions with closely agreeing results.

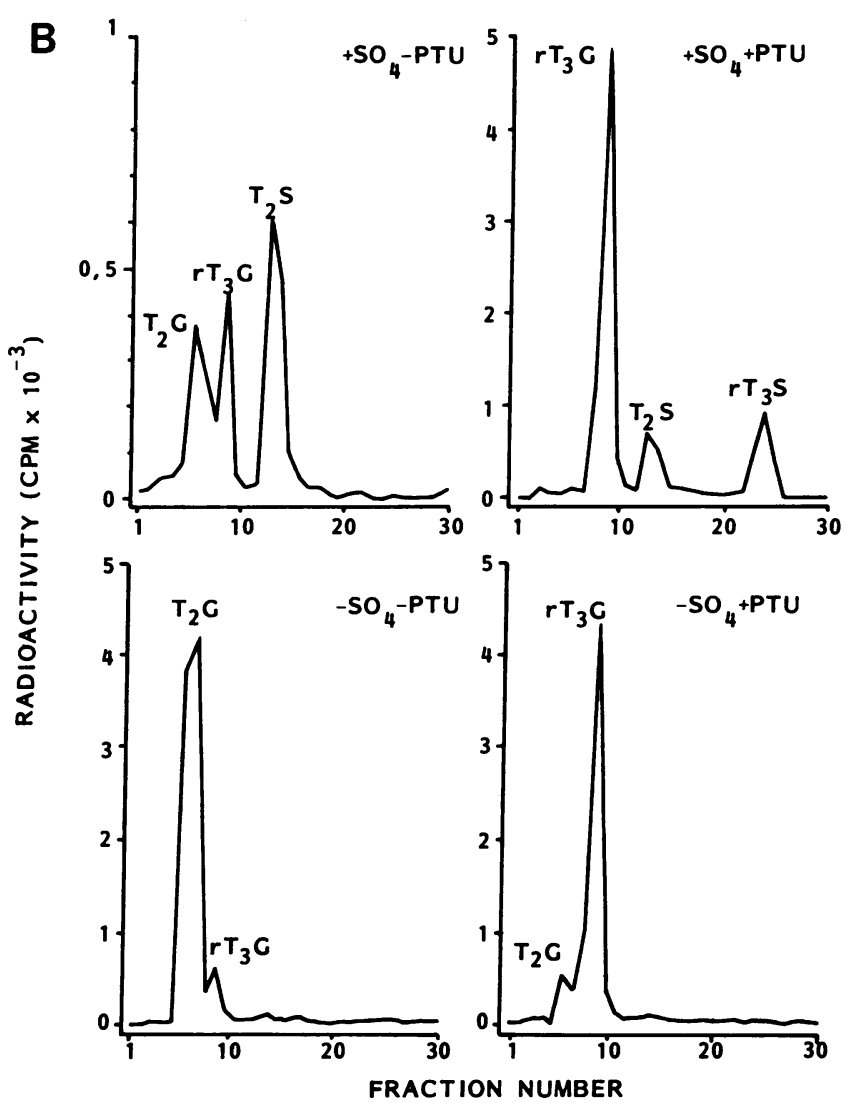

monium acetate $(\mathrm{pH} 4)$ at a flow of $0.6 \mathrm{ml} / \mathrm{min}$. Fractions of $0.3 \mathrm{ml}$ were collected and counted for radioactivity. Elution position of $\mathrm{S}$ conjugates was determined using synthetic standards and conjugates were further identified by enzymatic liberation of $3,3^{\prime}-\mathrm{T}_{2}$ or $\mathrm{rT}_{3}$ after treatment with sulfatase or glucuronidase. Radioactivity eluting in the position of $\mathrm{rT}_{3} \mathrm{~S}$ was not hydrolyzed by sulfatase, in agreement with previous observations using synthetic $\mathrm{rT}_{3} \mathrm{~S}$ (13).

18). These workers also provided evidence for the conversion of both $T_{3}$ and $\mathrm{rT}_{3}$ to $3,3^{\prime}-\mathrm{T}_{2}$ in vivo by demonstration of the presence of radioactive $3,3^{\prime}-T_{2}$ in the kidney after administration of labeled $\mathrm{T}_{3}$ or $\mathrm{rT}_{3}$ to thyroidectomized rats (19). In humans, most plasma 3,3'- $T_{2}$ originates from IRD of $T_{3}(20,21)$. Plasma $3,3^{\prime}-\mathrm{T}_{2}{ }^{2}(22)$ and $\mathrm{rT}_{3}{ }^{2}$ are cleared predominantly by the liver, which indicates that they are derived from extrahepatic IRD of $T_{3}$ and $T_{4}$, respectively. It is likely that these processes are catalyzed by the type III deiodinase, which specifically acts on the inner ring of iodothyronines and which has been localized in tissues such as brain and skin but not in liver $(2,5)$. In our studies we focused on the role of the type I deiodinase in the hepatic clearance of $\mathrm{rT}_{3}$.

Numerous studies have appeared on the characteristics of the deiodination of different iodothyronines by homogenates and subcellular fractions of rat liver (for a review, see reference 2). These studies have established the existence of a so-called type I deiodinase in the endoplasmic reticulum, which is an integral membrane protein and requires thiols for deiodinase activity. The enzyme is a nonspecific deiodinase that is capable of removing iodines from either ring of iodothyronine substrates (2). However, the enzyme is most effective in the ORD of $\mathrm{rT}_{3}$ $(2,23)$. To test the possible regulatory function of this enzyme in peripheral thyroid hormone metabolism, we have therefore initiated studies of the breakdown of $\mathrm{rT}_{3}$ by isolated rat hepa- 
Table II. Effects of SAM and DCNP on Medium

Free $r T_{3}$ and 3,3'- $T_{2}$ Levels, on Microsomal

Deiodinase Activity, and on Cellular ATP Content

\begin{tabular}{|c|c|c|c|c|c|}
\hline \multirow[b]{2}{*}{ Treatment } & & \multicolumn{2}{|c|}{$\begin{array}{l}\text { Free fraction } \\
(\%)^{*}\end{array}$} & \multirow{2}{*}{$\begin{array}{l}\text { Deiodinase } \\
\text { activity }\end{array}$} & \multirow[b]{2}{*}{ ATPA } \\
\hline & & $\mathrm{rT}_{3}$ & $3,3^{\prime}-T_{2}$ & & \\
\hline & & & & Control (\%) & Control (\%) \\
\hline Control & & 4.9 & 8.5 & 100 & 100 \\
\hline \multirow[t]{3}{*}{ SAM } & $10 \mu \mathrm{M}$ & 4.4 & 8.7 & 107 & 100 \\
\hline & $100 \mu \mathrm{M}$ & 4.6 & 8.4 & 103 & 85 \\
\hline & $1,000 \mu \mathrm{M}$ & 4.8 & 8.7 & 77 & 94 \\
\hline \multirow[t]{2}{*}{ DCNP } & $10 \mu \mathrm{M}$ & 6.0 & 8.8 & 89 & 97 \\
\hline & $100 \mu \mathrm{M}$ & 7.8 & 9.2 & 35 & 67 \\
\hline
\end{tabular}

* Free iodothyronine levels in medium were determined in triplicate by equilibrium dialysis.

₹ Deiodinase activity was measured in triplicate in mixtures of $10 \mathrm{nM}$ $\left[{ }^{125} \mathrm{I}\right] \mathrm{rT}{ }_{3}, 2$ or $5 \mu \mathrm{g}$ microsomal protein/ml, and $5 \mathrm{mM}$ DTT in $0.1 \mathrm{M}$ phosphate (pH 7.2) and 2 mM EDTA (14). After incubation for 15 min at $37^{\circ} \mathrm{C}$, reactions were halted by addition of serum, and ${ }^{125} \mathrm{I}^{-}$released was measured by TCA precipitation. Data are expressed as the means of the six observations relative to iodide production in the absence of inhibitors.

Cells were incubated for $1 \mathrm{~h}$ at $37^{\circ} \mathrm{C}$ with Dulbecco's medium plus $\mathrm{S}$ and the indicated concentrations of SAM and DCNP. ATP was measured in $0.2-\mathrm{M}$ perchloric acid extracts $\left(0.5 \mathrm{ml} / 10^{6}\right.$ cells $)$ after centrifugation and neutralization with $2 \mathrm{M} \mathrm{KOH}$ according to the method of Jaworek et al. (15). Data are taken from a representative experiment repeated under different conditions with similar results.

tocytes. In spite of the high rate of $\mathrm{rT}_{3}$ to $3,3^{\prime}-\mathrm{T}_{2}$ conversion with isolated microsomes, and the stability of the product in such incubations (23), surprisingly little production of $3,3^{\prime}-\mathrm{T}_{2}$ from $\mathrm{rT}_{3}$ was observed in incubations with intact liver cells (8). That nevertheless rapid ORD took place in this system was demonstrated by the large amounts of radioiodide released from outer ring labeled $\mathrm{rT}_{3}(8)$. This implies that any $3,3^{\prime}-\mathrm{T}_{2}$ formed would have undergone further deiodination, as substantiated by analysis of the metabolism of added 3,3'- $T_{2}$. Similar rapid degradation of both $\mathrm{rT}_{3}$ and 3,3'- $\mathrm{T}_{2}$ with extensive $\mathrm{I}^{-}$formation was observed by Flock et al. (24) in isolated rat liver perfusions. The unexpected rapid deiodination of $3,3^{\prime}-\mathrm{T}_{2}$ in rat liver cells in contrast to microsomes was subsequently shown to be due to the efficient sulfation of $3,3^{\prime}-T_{2}$ in hepatocytes yielding $3,3^{\prime}-T_{2} S$, a highly effective substrate for the type I deiodinase (10). A similar facilatory effect of $S$ conjugation has been described for the IRD of $T_{3}$ and $T_{4}$ $(25,26)$.

In the present study, we tested the hypothesis that it is possible to demonstrate production of $3,3^{\prime}-\mathrm{T}_{2}$ from $\mathrm{rT}_{3}$ in this system if further metabolism, especially sulfation, of $3,3^{\prime}-T_{2}$ is prevented. In experiments with isolated rat hepatocytes three methods are available in principle to manipulate the sulfotransferase activity of the cells. Firstly, it has been demonstrated that there is a rapid equilibrium between medium and cellular inorganic $S$ levels (27-29). Rat liver cells also have the capacity to generate $S$ by oxidation of the sulfur-containing amino acids methionine and cysteine (28). Therefore, considerable $S$ depletion is obtained by keeping cells in medium without $S$ and possible precursors. Secondly, sulfation of phenolic substances may be prevented by competitive substrates (30). SAM has been shown to undergo extensive sulfation and at higher concentrations also glucuronidation in rat liver cells. For instance, Koike et al. (29) have reported that in isolated rat hepatocytes, sulfation of SAM is characterized by an apparent $K_{m}$ value of $6 \mu \mathrm{M}$ with a $V_{\max }$ value of $2 \mathrm{nmol} / \mathrm{min}$ per $10^{6}$ cells at $1.2 \mathrm{mM}$ inorganic $S$ in the medium. This level of $S$ is similar to that used in our system (1 $\mathrm{mM}$ ), providing near-maximal rates of $S$ conjugation $(9,10)$. Glucuronidation of SAM became more pronounced if the competing pathway of sulfation was saturated at high SAM levels or prevented by $S$ depletion (29). $G$ conjugation occured with a $\mathrm{K}_{\mathrm{m}}$ value of $0.2 \mathrm{mM}$ and $\mathrm{V}_{\max }$ of $1.3 \mathrm{nmol} / \mathrm{min}$ per $10^{6}$ cells as determined under S-depleted conditions. Thirdly, specific inhibition of phenol sulfotransferase activity may be obtained using DCNP, a compound which in itself is not sulfated $(31,32)$. All three abovementioned ways of intervention with the further sulfation of $3,3^{\prime}-T_{2}$ have been applied to our study of the deiodination of $\mathrm{rT}_{3}$ by rat hepatocytes.

Previous studies from our laboratory have demonstrated the feasibility of using small Sephadex LH-20 columns for separation of $3,3^{\prime}-\mathrm{T}_{2}$ and its main metabolites, $3,3^{\prime}-\mathrm{T}_{2} \mathrm{~S}$ and $\mathrm{I}^{-}(10)$. We have adapted this method in the present investigation for the analysis of $\mathrm{rT}_{3}$ metabolites. With this modification it was possible to separate fractions containing $\mathrm{I}^{-}$, conjugates, $3,3^{\prime}-\mathrm{T}_{2}$, and $\mathrm{rT}_{3}$, respectively. Since the fraction eluted with water may contain various conjugates, and also because there is a slight contamination of the $3,3^{\prime}-\mathrm{T}_{2}$ fraction with $\mathrm{rT}_{3}$, these analyses were extended by HPLC and RIA determinations. Despite the limitations of the Sephadex LH-20 method, a good correlation between $3,3^{\prime}-T_{2}$ production rates as measured by the three different techniques was observed.

Time-course studies of the metabolism of $3,3^{\prime}-\mathrm{T}_{2}$ and $\mathrm{rT}_{3}$ demonstrated that under the conditions used, i.e., 10-nM substrate levels and S-supplemented cells, clearance of both substances follows first-order rate kinetics (Fig. 2). Such kinetics were also observed in the presence of $100 \mu \mathrm{M}$ SAM, which did not affect the rate constant for $\mathrm{rT}_{3}$ but lowered that for $3,3^{\prime}-\mathrm{T}_{2}$ by $77 \%$. These results show that conjugation is an important, rate-limiting step in the metabolism of $3,3^{\prime}-T_{2}$, but not of $\mathrm{rT}_{3}$. SAM does not only inhibit degradation of added $3,3^{\prime}-T_{2}$, but apparently also that of $3,3^{\prime}-\mathrm{T}_{2}$ produced from $\mathrm{rT}_{3}$. No evidence was obtained by HPLC for the generation of iodothyronines other than $3,3^{\prime}-\mathrm{T}_{2}$ such as $3^{\prime}, 5^{\prime}-\mathrm{T}_{2}$ or $3^{\prime}$-iodothyronine (Fig. 3).

The 100- $\mu$ M SAM concentration used mostly in our experiments was shown to have near-maximal effects on the clearance of 3,3'- $T_{2}$. The generation of conjugates observed in the presence of PTU is inhibited to only a slightly greater extent at $1,000 \mu \mathrm{M}$ SAM, while $10 \mu \mathrm{M}$ of this drug already provided $60 \%$ inhibition. This value is in excellent agreement with the Michaelis constant $\left(K_{\mathrm{m}}\right)$ value for SAM sulfation of $6 \mu \mathrm{M}$, which was reported by Koike et al. (29). Note that after incubation of $3,3^{\prime}-\mathrm{T}_{2}$ in the presence of PTU, substantial radioactivity in the form of 3,3'$\mathrm{T}_{2} \mathrm{~S}$ remains associated with the cells, which suggests that exit of cellular $3,3^{\prime}-\mathrm{T}_{2} \mathrm{~S}$ is a relatively slow process. If the amount of cell-bound 3, $3^{\prime}-\mathrm{T}_{2} \mathrm{~S}$ is taken into account is is obvious that PTU does not affect clearance of $3,3^{\prime}-\mathrm{T}_{2}$, whereas metabolism of $\mathrm{rT}_{3}$ is strongly impaired (see below). In the absence of PTU, SAM induces a dose-dependent decrease in $\mathrm{I}^{-}$formation from $3,3^{\prime}-\mathrm{T}_{2}$ that parallels the decrease of $3,3^{\prime}-\mathrm{T}_{2} \mathrm{~S}$ in incubations with PTU. However, $\mathrm{I}^{-}$production is not completely suppressed with even $1,000 \mu \mathrm{M}$ SAM, suggesting that direct ORD of $3,3^{\prime}-\mathrm{T}_{2}$ may occur to some extent if sulfation is inhibited. Direct ORD of $3,3^{\prime}-\mathrm{T}_{2}$ has also been observed with isolated rat liver microsomes, albeit with only $2 \%$ of the efficiency of $3,3^{\prime}-T_{2} S$ ORD (9). Therefore, 
with unimpeded sulfation, direct deiodination is a negligible pathway.

Also concerning the accumulation of $3,3^{\prime}-\mathrm{T}_{2}$ produced from $\mathrm{rT}_{3}, 1,000 \mu \mathrm{M}$ SAM shows only slightly greater effects than 100 $\mu \mathrm{M}$ of this drug, while roughly a half-maximal effect is observed with $10 \mu \mathrm{M}$ SAM. At the highest SAM concentration, 3,3'- $\mathbf{T}_{2}$ represents approximately one-third and $\mathrm{I}^{-}$approximately twothirds of the $\mathrm{rT}_{3}$ metabolites, which corresponds to a $70 \%$ protection against further degradation of the $3,3^{\prime}-\mathrm{T}_{2}$ produced. It should be stressed that clearance of $\mathrm{rT}_{3}$ is not affected by even $1,000 \mu \mathrm{M}$ SAM. If added to deiodinase assay mixtures of $\mathrm{rT}_{3}$ with microsomes, inhibition was observed only with $1,000 \mu \mathrm{M}$ SAM (Table II). The differential effects of $1,000 \mu \mathrm{M}$ SAM on $\mathrm{rT}_{3}$ deiodination by intact cells, and that by isolated microsomes, indicate that intracellular SAM levels are substantially lower than those added to the medium. The extremely rapid metabolism of SAM by both sulfation and glucuronidation (29) may be an important factor contributing to this difference. The lack of effect of SAM on medium free iodothyronine levels and cellular ATP (Table II) further underscores the usefulness of this compound in studies of the conjugation of thyroid hormone.

Table I illustrates that similar effects on the metabolism of $3,3^{\prime}-\mathrm{T}_{2}$ and $\mathrm{rT}_{3}$ are obtained with $100 \mu \mathrm{M}$ DCNP as with 100 $\mu \mathrm{M}$ SAM. However, DCNP also exhibits some unwanted side effects. DCNP has been shown by Mulder and co-workers to be a specific inhibitor of sulfation in vivo as well as in vitro without being sulfated itself $(31,32)$. This compound does not affect glucuronidation and was reported to have no major toxic effects, which is in contrast with our findings that show a substantial decrease in cellular ATP by $100 \mu \mathrm{M}$ DCNP. This effect on ATP may be related to the toxic effects on oxidative phosphorylation generally observed with phenols $(33,34)$ which may be promoted by the relative deficiency of nutrients and oxygen in our system. A further disadvantage of DCNP is that it may inhibit deiodinase activity directly, as demonstrated by the influence of DCNP in incubations with microsomes (Table II). Similar to SAM, however, intracellular DCNP concentrations may be substantially lower than the total concentrations added to the medium. One possible reason for this is that DCNP binds extensively to BSA (31). The decreased availability of DCNP to the cells, therefore, prevents direct inhibition of the deiodinase, and metabolism of $\mathrm{rT}_{3}$ is even stimulated by $100 \mu \mathrm{M}$ DCNP. This latter phenomenon is probably due to displacement of $\mathrm{rT}_{3}$ from BSA (Table II), which causes a shift of $\mathrm{rT}_{3}$ into the intracellular compartment. Nevertheless, results obtained with DCNP are in confirmation of the experiments with SAM which underscore the importance of sulfation for the metabolism of $3,3^{\prime}-\mathrm{T}_{2}$ but not of $\mathrm{rT}_{3}$.

The Sephadex LH-20 method used in this study does not permit the distinction of the different conjugates of $3,3^{\prime}-T_{2}$ and $\mathrm{rT}_{3}$. Previous findings have indicated that sulfate conjugates do not crossreact in RIAs of non-conjugated iodothyronines (13). The RIA data presented in Table I are, therefore, consistent with the results obtained by $\mathrm{LH}-20$ insofar as they indicate that clearance of $3,3^{\prime}-T_{2}$ is not inhibited by PTU. If the product that is formed from 3, $3^{\prime}-T_{2}$ in the presence of PTU is subjected to acid hydrolysis, similar amounts of $3,3^{\prime}-T_{2}$ are recovered as those measured after incubation with SAM or DCNP. Since iodothyronine sulfates are prone to acid hydrolysis (13), while glucuronides are much more resistant (Oosterlaken, T., S. J. Eelkman Rooda, and T. J. Visser, unpublished observations), this indicates accumulation of $3,3^{\prime}-\mathrm{T}_{2} \mathrm{~S}$ in the presence of PTU. However, most direct evidence for the identity of the conjugates is provided by
HPLC in combination with enzymatic analysis using sulfatase or glucuronidase. These experiments were made on samples from incubations with cells in different degrees of $S$ depletion.

S-deplete hepatocytes were prepared by preincubation with medium lacking inorganic $S$ and by using the same medium for incubation with substrate. The results obtained with $3,3^{\prime}-T_{2}$ in the presence of PTU showed that under these conditions S depletion was not complete, and led to some residual $3,3^{\prime}-\mathrm{T}_{2} \mathrm{~S}$ formation. Further exhaustion of cellular $S$ stores was obtained by preincubation with SAM. A similar approach has been followed by other investigators to reveal the significance of the conjugation reactions in the elimination of drugs $(35,36)$. Thus, substantial lowering of hepatic UDP-glucuronic acid and adenosine 3'phosphate 5'-phosphosulfate levels has been achieved by in vivo treatment with SAM due to the consumption of these co-factors in the glucuronidation and sulfation of the drug $(35,36)$. Application of a SAM load induces a prolonged lowering of body $S$ stores with pronounced decrements in plasma S levels (35), but depletion of tissue UDP-glucuronic acid is only transient, and co-factor levels are rapidly restored (36). We also obtained evidence for the reversible nature of these effects. After preincubation with SAM, 3, $\mathbf{3}^{\prime}-\mathrm{T}_{2}$ sulfation rates after readdition of $\mathrm{SO}_{4}{ }^{2-}$ and $\mathrm{T}_{3}$ glucuronidation rates (Eelkman Rooda, S. J., and T. J. Visser, unpublished observations) were completely normal.

In S-replete cells, sulfation is by far the predominant pathway of $3,3^{\prime}-\mathrm{T}_{2}$ metabolism, although little $3,3^{\prime}-\mathrm{T}_{2} \mathrm{~S}$ is recovered in the absence of PTU due to further deiodination. However, in S-deplete cells the contribution of the glucuronidation pathway increases, and results in augmented accumulation of $3,3^{\prime}-T_{2} G$ from added 3,3'- $T_{2}$, as well as from added $r T_{3}$. The latter findings indicate that glucuronidation does not facilitate deiodination of $3,3^{\prime}-T_{2}$, which is in contrast to the stimulatory effects of sulfation. Although ORD is the foremost step in the hepatic metabolism of $\mathrm{rT}_{3}$, some glucuronidation of this metabolite is observed, especially in the presence of PTU. The low rate of $\mathrm{rT}_{3}$ sulfation in comparison with the highly efficient sulfation of $3,3^{\prime}-\mathrm{T}_{2}$ is in agreement with data of the structure-activity relationship for the sulfation of iodothyronines by isolated phenol sulfotransferases (37).

The effects of substrate concentration on the conversion of $\mathrm{rT}_{3}$ to $3,3^{\prime}-\mathrm{T}_{2}$ by rat liver cells indicate that half-maximal $3,3^{\prime}$ $\mathrm{T}_{2}$ production is obtained between 10 and $100 \mathrm{nM} \mathrm{rT}_{3}$. This is in the same concentration range as the $K_{\mathrm{m}}$ value determined for $\mathrm{rT}_{3}$ ORD in reactions with microsomes and DTT (23). However, the $\mathrm{rT}_{3}$ levels in the culture medium are largely protein bound and certainly do not reflect intracellularly available substrate concentrations. Together with the uncertainty about the saturation kinetics of the type I deiodinase in its natural environment it is, therefore, impossible to interpret these findings in terms of a possible uphill gradient of $\mathrm{rT}_{3}$ across the cell membrane (38).

In conclusion, our results demonstrate that in isolated rat hepatocytes, $\mathrm{rT}_{3}$ is metabolized almost exclusively by ORD. However, the immediate product of this reaction, $3,3^{\prime}-T_{2}$, is not observed unless its further metabolism by successive sulfation and deiodination is inhibited. Evidence for formation of $3^{\prime}, 5^{\prime}-$ $T_{2}$ in these studies was not obtained. In different clinical situations, plasma $T_{3}$ and $r T_{3}$ levels change in opposite directions due to parallel alterations in the rate of $T_{3}$ production and $r T_{3}$ degradation. This is understandable, as both processes concern ORD reactions mediated by common enzymes among which the type I deiodinase of the liver plays an important function. It is expected, therefore, that a detailed knowledge of the ORD 
of $\mathrm{rT}_{3}$ by intact liver cells will deepen our insight into the regulation of the bioavailability of thyroid hormone.

\section{References}

1. Engler, D., and A. G. Burger. 1984. The deiodination of the iodothyronines and of their derivatives in man. Endocrine Rev. 5:151184.

2. Leonard, J. L., and T. J. Visser. 1986. Biochemistry of deiodination. In Thyroid Hormone Metabolism. G. Hennemann, editor. Marcel Dekker, New York. 189-229.

3. Silva, J. E., and P. R. Larsen. 1985. Potential of brown adipose tissue type II $\mathrm{T}_{4} 5^{\prime}$-deiodinase as a local and systemic source of triiodothyronine in rats. J. Clin. Invest. 76:2296-2305.

4. Hidal, J. T., and M. M. Kaplan. 1985. Characteristics of thyroxine 5 '-deiodination in cultured human placental cells. Regulation by iodothyronines. J. Clin. Invest. 76:947-955.

5. Huang, T.-S., I. J. Chopra, A. Beredo, D. H. Solomon, and G. M. Chua Teco. 1985. Skin is an active site for the inner ring monodeiodination of thyroxine to 3,3',5'-triiodothyronine. Endocrinology 117:21062113.

6. Silva, J. E., M. B. Gordon, F. R. Crantz, J. L. Leonard, and P. R. Larsen. 1984. Qualitative and quantitative differences in the pathways of extrathyroidal triiodothyronine generation between euthyroid and hypothyroid rats. J. Clin. Invest. 73:898-907.

7. Wartofsky, L., and K. D. Burman. 1982. Alterations in thyroid function in patients with systemic illness: "The euthyroid sick syndrome". Endocrine Rev. 3:164-217.

8. Visser, T. J., M. H. Otten, J. A. Mol, R. Docter, and G. Hennemann. 1984. Sulfation facilitates hepatic deiodination of iodothyronines. Horm. Metab. Res. 14(Suppl.):35-41.

9. Otten, M. H., J. A. Mol, and T. J. Visser. 1983. Sulfation preceeding deiodination of iodothyronines in rat hepatocytes. Science (Wash. DC). 221:81-83.

10. Otten, M. H., G. Hennemann, R. Docter, and T. J. Visser. 1984. Metabolism of 3,3'-diiodothyronine in rat hepatocytes: interaction of sulfation with deiodination. Endocrinology. 115:887-894.

11. Visser, T. J., L. M. Krieger-Quist, R. Docter, and G. Hennemann. 1978. Radioimmunoassay of 3,3'-diiodothyronine in unextracted serum: the effect of endogenous tri-iodothyronine. J. Endocrinol. 79:357-362.

12. Visser, T. J., R. Docter, and G. Hennemann. 1977. Radioimmunoassay of reverse-triiodothyronine. J. Endocrinol. 73:395-396.

13. Mol, J. A., and T. J. Visser. 1985. Synthesis and some properties of sulfate esters and sulfamates of iodothyronines. Endocrinology. 117: $1-7$.

14. Mol, J. A., R. Docter, G. Hennemann, and T. J. Visser. 1984. Modification of rat liver iodothyronine 5'-deiodinase activity with diethylpyrocarbonate and rose bengal: evidence for an active site histidine residue. Biochem. Biophys. Res. Commun. 120:28-36.

15. Jaworek, D., W. Gruber, and H. U. Bergmeyer. 1974. Adenosine5'-triphosphate: determination with 3-phosphoglycerate kinase. In Methods of Enzymatic Analysis. Vol. 1. H. U. Bergmeyer and H. Gawehn, editors. Verlag Chemie, Weinheim. 2097-2101.

16. Roche, J., R. Michel, J. Nunez, and W. Wolf. 1955. Sur deux constituants hormonaux nouveaux du corps thyroide: la 3,3'-diiodothyronine et la 3,3',5'-triiodothyronine. Biochim. Biophys. Acta. 18:149157.

17. Roche, J., R. Michel, J. Nunez, and W. Wolf. 1955. Sur la presence dans le plasma de la 3,3'-diiodothyronine, nouvelle hormone thyroidienne. C. R. Soc. Biol. 149:884-887.

18. Roche, J., R. Michel, and J. Nunez. 1956. Sur la presence de la 3,3',5'-triiodothyronine dans le sang de rat. C.R. Soc. Biol. 150:20-25.

19. Roche, J., R. Michel, J. Nunez, and C. Jaquemin. 1959. On the metabolism of 3,3'-diiodothyronine and 3,3'-5'-triiodothyronine. Endocrinology. 65:402-407.

20. Engler, D., U. Merkelbach, G. Steiger, and A. G. Burger. 1983. The monodeiodination of triiodothyronine and reverse triiodothyronine in man: A quantitative evaluation of the pathway by the use of turnover rate techniques. J. Clin. Endocrinol. Metab. 58:49-61.

21. Zucchelli, G. C., A. Pilo, D. Giannessi, R. Bianchi, F. Cazzuola, and N. Molea. 1980. Labeled metabolites appearing in human serum after ${ }^{125}$ I-triiodothyronine $\left(\mathrm{T}_{3}\right)$ administration: a quantative reappraisal. Metab. Clin. Exp. 29:1031-1036.

22. Faber, J., O. K. Faber, and B. Lund, C. Kirkegaard, and J. Wahren. 1980. Hepatic extraction and renal production of 3,3'-diiodothyronine and 3',5'-diiodothyronine in man. J. Clin. Invest. 66:941-945.

23. Visser, T. J., D. Fekkes, R. Docter, and G. Hennemann. 1979. Kinetics of enzymatic reductive deiodination of iodothyronines. Biochem. J. 179:489-495.

24. Flock, E. V., and C. A. Owen. 1965. Metabolism of thyroid hormones and some derivatives in isolated, perfused rat liver. Am. J. Physiol. 209:1039-1045.

25. Visser, T. J., J. A. Mol, and M. H. Otten. 1983. Rapid deiodination of triiodothyronine sulfate by rat liver microsomal fraction. Endocrinology. 112:1547-1549.

26. Mol, J. A., and T. J. Visser. 1985. Rapid and selective inner ring deiodination of thyroxine sulfate by rat liver deiodinase. Endocrinology. 117:8-12.

27. Moldeus, P., B. Andersson, and V. Gergely. 1979. Regulation of glucuronidation and sulfate conjugation in isolated hepatocytes. Drug. Metab. Dispos. 7:416-419.

28. Schwarz, L. R. 1980. Modulation of sulfation and glucuronidation of 1-naphthol in isolated rat liver cells. Arch. Toxicol. 44:137-145.

29. Koike, M., K. Sugeno, and M. Hirata. 1981. Sulfoconjugation and glucuronidation of salicylamide in isolated rat hepatocytes. J. Pharm. Sci. 70:308-311.

30. Levy, G., and H. Yamada. 1971. Drug biotransformation interactions in man III: acetaminophen and salicylamide. J. Pharm. Sci. 60: 215-221.

31. Koster, H., I. Halsema, E. Scholtens, J. H. N. Meerman, K.-S. Pang, and G. J. Mulder. 1982. Selective inhibition of sulfate conjugation in the rat. Pharmacokinetics and characterization of the inhibitory effect of 2,6-dichloro-4-nitrophenol. Biochem. Pharmacol. 10:1919-1924.

32. Koster, H., I. Halsema, E. Scholtens, K.-S. Pang, and G. J. Mulder. 1982. Kinetics of sulfation and glucuronidation of harmol in the perfused rat liver preparation. Disappearance of aberrances in glucuronidation kinetics by inhibition of sulfation. Biochem. Pharmacol. 31:3023-3028.

33. Wynn, J., and W. Fore. 1965. The effect of hindered phenols on mitochondrial oxidative phosphorylation. J. Biol. Chem. 240:1766-1771.

34. Dills, R. L., and C. D. Klaassen. 1986. The effect of inhibitors of mitochondrial energy production on hepatic glutathione, UDP-glucuronic acid, and adenosine $3^{\prime}$-phosphate-5'-phosphosulfate concentrations. Drug Metab. Dispos. 14:190-196.

35. Waschek, J. A., R. M. Fielding, S. M. Pond, G. M. Rubin, D. J. E. Effeney, and T. N. Tozer. 1985. Dose-dependent sulfoconjugation of salicylamide in dogs: effect of sulfate depletion or administration. $J$. Pharmacol. Exp. Ther. 234:431-434.

36. Howell, S. R., G. A. Hazelton, and C. D. Klaassen. 1986. Depletion of hepatic UDP glucuronic acid by drugs that are glucuronidated. J. Pharmacol. Exp. Ther. 236:610-614.

37. Sekura, R. D., K. Sato, H. J. Cahnmann, J. Robbins, and W. B. Jakoby. 1981. Sulfate transfer to thyroid hormones and their analogs by hepatic aryl sulfotransferases. Endocrinology. 108:454-456.

38. Krenning, E., R. Docter, B. Bernard, T. J. Visser, and G. Hennemann. 1981. Characteristics of active transport of thyroid hormone into rat hepatocytes. Biochim. Biophys. Acta. 676:314-320. 